\title{
Response of tomato (Solanum lycopersicum L.) to fertigation by irrigation scheduling in drip irrigation system
}

\author{
Ankush $^{* 1}$, Vikram Singh ${ }^{2}$ and S. K. Sharma ${ }^{1}$ \\ ${ }^{1}$ Department of Agricultural Chemistry and Soil Science, Rajasthan College of Agriculture, MPUAT, \\ Udaipur-313001 (Rajasthan), INDIA \\ ${ }^{2}$ Department of Agronomy, Chaudhary Charan Singh Haryana Agricultural University, Hisar-125001 (Haryana), \\ INDIA \\ *Corresponding author. E-mail: ktankdhanda@gmail.com
}

Received: September 25, 2016; Revised received: February 23, 2017; Accepted: May 20, 2017

\begin{abstract}
Drip irrigation technique has proved its superiority over other methods of irrigation due to direct application of water and nutrient in the vicinity of root zone. A field study was conducted to evaluate the effect of irrigation and fertigation scheduling through drip irrigation in tomato (Solanum lycopersicum L.) during Rabi season of 201516 at Rajasthan College of Agriculture, MPUAT, Udaipur. There were three irrigation levels and five fertilization levels in split-plot design with three replications. Nutrient content in plant and fruit was found higher under the application of drip irrigation at $100 \% \mathrm{PE}\left(\mathrm{I}_{1}\right)$ and at $100 \%$ RDF through fertigation $\left(\mathrm{F}_{1}\right)$. Maximum nutrient uptake by tomato i.e. nitrogen $\left(166.83 \mathrm{~kg} \mathrm{ha}^{-1}\right)$, phosphorus $\left(41.59 \mathrm{~kg} \mathrm{ha}^{-1}\right)$ and potassium $\left(183.08 \mathrm{~kg} \mathrm{ha}^{-1}\right)$ was recorded with treatment combination of drip irrigation at $75 \% \mathrm{PE}\left(\mathrm{I}_{2}\right)+75 \%$ RDF through fertigation +2 foliar spray of $1 \%$ urea phosphate $\left(F_{3}\right)$. Similarly, significantly maximum yield and growth attributes i.e. fruit yield $\left(201.25 \mathrm{q}\right.$ ha $\left.{ }^{-1}\right)$, plant height $(67.43 \mathrm{~cm})$ and number of branches (12.33) were registered with treatment combination of drip irrigation at 75 $\% \mathrm{PE}$ and $75 \%$ RDF through fertigation +2 foliar spray of $1 \%$ urea phosphate. Drip fertigation method has proved to be very significant in improving nutrient uptake which finally resulting in enhancement of growth and yield of tomato crop.
\end{abstract}

Keywords: Fertigation, Growth, Nutrient content and uptake, Tomato, Yield

\section{INTRODUCTION}

Tomato (Solanum lycopersicum L.) is an important and widely grown solanaceous vegetable crop around the world and belongs to the family Solanaceae. It is considered an important source of vitamin A, C and minerals (Hari, 1997). Apart from this, lycopene is valued for its anti-cancer property. Water supply is major constraint to crop production. Water is the source of life and has a special place in our planet. Efficient use of water by irrigation is becoming increasingly important, and alternative water application method such as drip, may contribute substantially to the best use of water for agriculture. With the drip irrigation systems, water and nutrients can be applied directly to the crop at the root level, having positive effects on nutrient uptake, yield and water saving and increasing the irrigation performance (Nagaz et al., 2012). Drip irrigation is an advanced system through which water can be applied precisely, judiciously and uniformly with the help of regulatory system direct to the root of the crop. At the same time, adequate fertilization both in time and through method application to maintain optimum nutrient supply for optimum growth and development of the crop are also equally important towards the higher productivity (Nijamodeen and Dharmasena, 2002). Drip irrigation include improves nutrient content and uptake, increase plant growth and development, higher yield in scheduling water application. Application of water soluble fertilizer through micro-irrigation system like drip (fertigation) is gaining importance in present day agriculture to boost the production and productivity of various crops. With this background, the present study was conducted on filed grown tomato with the objectives: i) To study the effect of various irrigation and fertigation scheduling on nutrient content and uptake of tomato crop ii) To study the effect of NPK drip fertigation on growth and yield of tomato crop.

\section{MATERIALS AND METHODS}

The experiment was conducted at field no. C3, Department of Horticulture, Rajasthan College of Agriculture, Maharana Partap University of Agriculture and Technology (MPUAT), Udaipur. The region falls under agro-climatic zone IVA (Sub- Humid Southern Plain and Aravalli Hills) of Rajasthan. The soil of the experimental area belongs to clay loam in texture. The physic-chemical properties of soil are given in Table 1 . The experiment was laid out in split plot design and replicated three times with fifteen fertigation treatment 
Table 1. Physio-chemical properties of Udaipur soil (clay loam soils).

\begin{tabular}{ll}
\hline Physio-chemical properties & \\
\hline $\mathrm{pH}(1: 2$, soil : water) & 8.15 \\
Bulk density $\left(\mathrm{Mg} \mathrm{m}^{-3}\right)$ & \\
Particle density $\left(\mathrm{Mg} \mathrm{m}^{-3}\right)$ & \\
Porosity $(\%)$ & 1.52 \\
Organic carbon (\%) & 0.71 \\
DTPA-extractable copper $\left(\mathrm{mg} \mathrm{kg}^{-1}\right)$ & 1.98 \\
DTPA-extractable zinc $\left(\mathrm{mg} \mathrm{kg}^{-1}\right)$ & 1.78 \\
EC $\left(\mathrm{dSm}^{-1}\right)(1: 2$, soil: water) & 0.67 \\
Available nitrogen $\left(\mathrm{kg} \mathrm{N} \mathrm{ha}^{-1}\right)$ & 296.45 \\
Available phosphorus $\left(\mathrm{kg} \mathrm{P}_{2} \mathrm{O}_{5} \mathrm{ha}^{-1}\right)$ & 23.76 \\
Availablepotassium $\left(\mathrm{kg} \mathrm{K}_{2} \mathrm{O} \mathrm{ha}\right.$ & -1 \\
DTPA-extractable iron $\left(\mathrm{mg} \mathrm{kg}^{-1}\right)$ & 318.65 \\
DTPA-extractable manganese $\left(\mathrm{mg} \mathrm{kg}^{1}\right)$ & 5.98 \\
\hline
\end{tabular}

combinations. The treatments include three levels of irrigation water viz., $100 \%, 75 \%$ and $50 \% \mathrm{PE}$ through drip and five levels of fertilizations viz., 100 $\%$ RDF, $75 \%$ RDF, $75 \%$ RDF through fertigation +2 foliar spray of $1 \%$ urea phosphate, $50 \%$ RDF and 50 $\%$ RDF through fertigation +2 foliar spray of $1 \%$ urea phosphate. Irrigation schedules were planned to provide the estimated water requirement of the crop. Irrigation was schedules based on the three days interval water requirement of the crop. In order to determine the optimum water requirement for crops, three irrigation levels were adopted with 100, 75 and 50 percent (PE) water requirement of the crop. The discharge rate of the emitter was 2.5 liters per hour at nominal pressure of $1.25 \mathrm{~kg} \mathrm{~cm}^{-2}$.

The quantity of irrigation water was calculated by using following formula (Vermerien and Jobling, 1980).

$\mathrm{ETc}=\mathrm{Epan} \times \mathrm{Kpan} \times \mathrm{Kc} \quad$.......(Eq. 1)

Where, ETc $=$ Evapotranspiration of crop $(\mathrm{mm})$, Epan $=$ Pan evaporation $(\mathrm{mm}), \mathrm{Kpan}=$ Pan Coefficient (0.7), $\mathrm{Kc}=$ Crop coefficient (as per growth stages)

Volume of water $=\mathrm{Ep} \times \mathrm{Kp} \times \mathrm{Kc} \times \mathrm{S}_{1} \times \mathrm{S}_{2} \times \mathrm{Wa} / \mathrm{E}$ ........(Eq. 2)

Where, $\mathrm{S}_{1}=$ Spacing between laterals $(\mathrm{M}), \mathrm{S}_{2}=$ Spac- ing between emitters $(\mathrm{M}), \mathrm{Wa}=$ Wetted Area $(\%), \mathrm{E}=$ Efficiency of System (\%). The operation time of the system ( $\mathrm{T}$ ) was calculated by using the following formula

$\mathrm{T}=\mathrm{V} / \mathrm{Q} \times \mathrm{Ne}$

where, $\mathrm{T}=$ Operating time of system (hrs.), $\mathrm{V}=$ Total volume of water (lit.), $\mathrm{q}=$ Emitter discharge (Lph), $\mathrm{Ne}$ $=$ Number of emitters plot ${ }^{-1}$. Scheduling of irrigation was done by using crop coefficient in drip irrigation (Doorenbos and Pruitt, 1977).

Fertigation with recommended fertilizer dose i.e. $180: 120: 80 \mathrm{~kg} \mathrm{NPK} / \mathrm{ha}$ was given according to the treatments in 6 split doses at 15 days interval beginning 10 days after transplanting. All other package of practices were adopted as recommended for the region. Observations on different growth and yield parameters were recorded from five randomly sampled plants from each treatment.

The method used for estimation of $\mathrm{N}$ was Microkjeldhal (Parkinson and Allen, 1975), for P Vanadomolybdate yellow colour method in nitric acid system (Jackson, 1973) and for K Flamephotometer (A.O.A.C., 2012). For this purpose the tomato plants were sundried first for a period of 10 days and then kept in hot air oven at $65^{\mathrm{O}} \mathrm{C}$ till constant weight was obtained. The dried plant samples were grinded in stainless still willey mill to fine powder and used for chemical analysis of $\mathrm{N}, \mathrm{P}$ and $\mathrm{K}$ content.

\section{RESULTS AND DISCUSSION}

\section{Nutrient content}

Effect of irrigation: The results in Table 2 revealed that nutrient content in plant i.e. nitrogen $(1.88 \%)$, phosphorus $(0.42 \%)$ and potassium $(1.94 \%)$ and in fruit i.e. nitrogen $(2.55 \%)$, phosphorus $(0.61 \%)$ and potassium $(2.72 \%)$ was significantly increased with the application of drip irrigation upto $100 \% \mathrm{PE}$ (I1) as compared to irrigation level $\mathrm{I} 2$ and $\mathrm{I} 3$. The maximum improvement in nitrogen, phosphorus and potassium

Table 2. Effect of drip irrigation and fertigation on N, P and K content (\%) in tomato plant and fruit at harvest.

\begin{tabular}{|c|c|c|c|c|c|c|}
\hline \multirow{2}{*}{ Treatments } & \multicolumn{3}{|c|}{ Tomato plant } & \multicolumn{3}{|c|}{ Tomato fruit } \\
\hline & Nitrogen & Phosphorus & Potassium & Nitrogen & Phosphorus & Potassium \\
\hline \multicolumn{7}{|c|}{ Irrigation levels } \\
\hline $\mathrm{I}_{1}$ & 1.88 & 0.42 & 1.94 & 2.55 & 0.61 & 2.72 \\
\hline $\mathrm{I}_{2}$ & 1.81 & 0.39 & 1.87 & 2.43 & 0.58 & 2.66 \\
\hline $\mathrm{I}_{3}$ & 1.76 & 0.34 & 1.81 & 2.39 & 0.54 & 2.59 \\
\hline C.D. $5 \%$ & 0.05 & 0.003 & 0.019 & 0.043 & 0.025 & 0.063 \\
\hline \multicolumn{7}{|c|}{ Fertilization levels } \\
\hline $\mathrm{F}_{1}$ & 1.91 & 0.43 & 1.95 & 2.56 & 0.63 & 2.78 \\
\hline $\mathrm{F}_{2}$ & 1.80 & 0.38 & 1.88 & 2.44 & 0.57 & 2.68 \\
\hline $\mathrm{F}_{3}$ & 1.84 & 0.42 & 1.96 & 2.48 & 0.62 & 2.77 \\
\hline $\mathrm{F}_{4}$ & 1.75 & 0.34 & 1.77 & 2.35 & 0.52 & 2.51 \\
\hline $\mathrm{F}_{5}$ & 1.80 & 0.36 & 1.82 & 2.44 & 0.55 & 2.54 \\
\hline C.D. $5 \%$ & 0.045 & 0.002 & 0.015 & 0.03 & 0.022 & 0.058 \\
\hline
\end{tabular}

$\mathrm{I}_{1}=$ Drip irrigation at $100 \% \mathrm{PE} ; \mathrm{I}_{2}=$ Drip irrigation at $75 \% \mathrm{PE} ; \mathrm{I}_{3}=$ Drip irrigation at $50 \% \mathrm{PE} ; \mathrm{F}_{1}=100 \% \mathrm{RDF}$ through fertigation; $\mathrm{F}_{2}=75 \%$ RDF through fertigation, $\mathrm{F}_{3}=75 \%$ RDF through fertigation +2 fpliar spray of $1 \%$ urea phosphate; $\mathrm{F}_{4}=50 \%$ RDF through fertigation; $\mathrm{F}_{5}=50 \%$ RDF through fertigation +2 foliar spray of $1 \%$ urea phosphate 
Ankush et al. / J. Appl. \& Nat. Sci. 9 (2): 1170 - 1175 (2017)
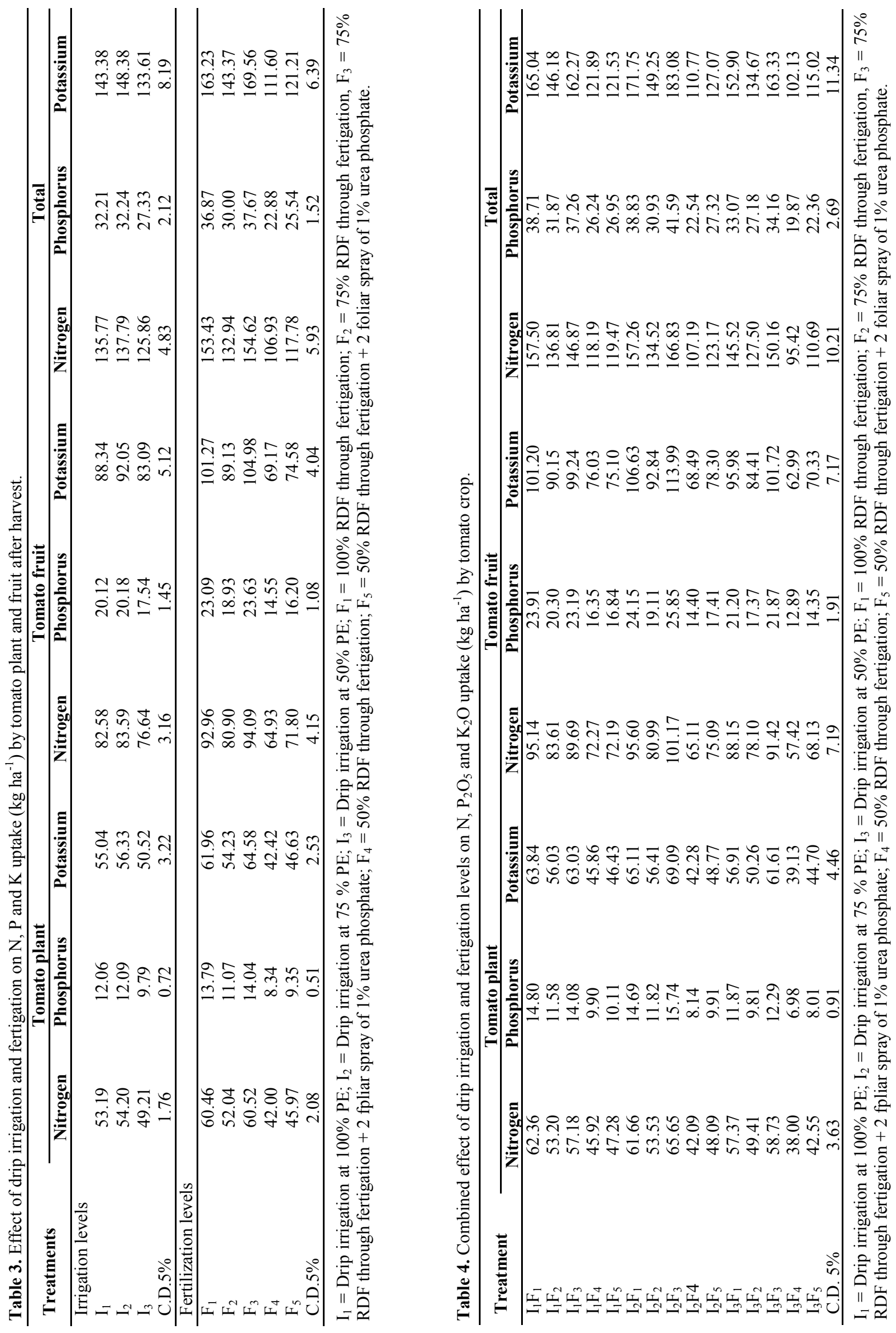
Ankush et al. / J. Appl. \& Nat. Sci. 9 (2): 1170 - 1175 (2017)

Table 5. Effect of drip irrigation and fertigation on growth characters yield of tomato.

\begin{tabular}{lccccc}
\hline Treatments & $\begin{array}{c}\text { Plant height } \\
\text { (cm) }\end{array}$ & $\begin{array}{c}\text { Number of } \\
\text { branches }\end{array}$ & $\begin{array}{c}\text { Average fruit } \\
\text { weight (gm) }\end{array}$ & $\begin{array}{c}\text { Average fruit yield } \\
\text { per plant (kg) }\end{array}$ & $\begin{array}{c}\text { Fruit yield (q } \\
\text { ha }^{-1} \text { ) }\end{array}$ \\
\hline Irrigation levels & & & & & 159.51 \\
\hline $\mathrm{I}_{1}$ & 51.97 & 8.27 & 88.91 & 2.75 & 169.03 \\
$\mathrm{I}_{2}$ & 55.83 & 9.00 & 95.32 & 2.19 & 157.0 \\
$\mathrm{I}_{3}$ & 51.10 & 7.67 & 87.59 & 0.12 & 8.57 \\
C.D.5\% & 2.72 & 0.96 & 3.79 & & 179.25 \\
\hline Fertilization Levels & & & & 2.98 & 163.38 \\
\hline $\mathrm{F}_{1}$ & 55.74 & 9.78 & 91.01 & 2.84 & 186.38 \\
$\mathrm{~F}_{2}$ & 53.98 & 8.44 & 90.28 & 3.25 & 135.61 \\
$\mathrm{~F}_{3}$ & 59.53 & 10.67 & 96.59 & 2.49 & 144.61 \\
$\mathrm{~F}_{4}$ & 45.29 & 5.33 & 85.38 & 2.67 & 7.23 \\
$\mathrm{~F}_{5}$ & 50.29 & 7.33 & 89.77 & 0.06 & \\
\hline C.D.5\% & 1.86 & 0.59 & 3.56 & & \\
\hline
\end{tabular}

$\mathrm{I}_{1}=$ Drip irrigation at $100 \% \mathrm{PE} ; \mathrm{I}_{2}=$ Drip irrigation at $75 \% \mathrm{PE} ; \mathrm{I}_{3}=$ Drip irrigation at $50 \% \mathrm{PE} ; \mathrm{F}_{1}=100 \%$ RDF through fertigation; $F_{2}=75 \%$ RDF through fertigation, $F_{3}=75 \%$ RDF through fertigation +2 fpliar spray of $1 \%$ urea phosphate; $F_{4}=50 \%$ RDF through fertigation; $\mathrm{F}_{5}=50 \% \mathrm{RDF}$ through fertigation +2 foliar spray of $1 \%$ urea phosphate.

content of tomato fruit and plant was recorded with higher level of drip irrigation which could be ascribed to better and timely availability of water and nutrients. Due to this, the force exerted by the plants to extract water and nutrients would be less and this might have enabled the crop to put forth better nutrient content in fruit and plant. These results are in conformity with the findings of Al-Mohammadi and Al-Zu'bi (2011) in tomato crop with higher dose of fertigation at flowering and fruiting stage and Vazquez et al. (2011) in cauliflower with plastic mulching.

Effect of fertigation: The results in Table 2 revealed that nutrient content in plant i.e. nitrogen $(1.91 \%)$, phosphorus $(0.43 \%)$ and potassium $(1.95 \%)$ and in fruit i.e. nitrogen $(2.56 \%)$, phosphorus $(0.63 \%)$ and potassium $(2.78 \%)$ was significantly higher under (F1) $100 \%$ RDF through fertigation. Higher nutrient content under the higher levels of fertigation as compared to other treatments might be due to frequent application of irrigation and fertilizer in drip with low concentration, for which the nutrients were effectively utilized as these were in direct contact with root system with negligible loss through leaching beyond the deeper depth of the soil profile. The findings are in the line of Badr et al. (2007) in chilli at higher $\mathrm{N}$ rate i.e. $300 \mathrm{~kg} \mathrm{ha}^{-1}$. Kohire and Das (2015) also reported higher nutrient content in chilli crop with $100 \%$ irrigation regime and $100 \%$ RDF through fertigation.

\section{Nutrient uptake}

Effect of irrigation: The results in Table 3 resulted that nutrient uptake by plant i.e. nitrogen $(54.20 \mathrm{~kg} \mathrm{ha}$ $\left.{ }^{1}\right)$, phosphorus $\left(12.09 \mathrm{~kg} \mathrm{ha}^{-1}\right)$ and potassium $(56.33 \mathrm{~kg}$ $\left.\mathrm{ha}^{-1}\right)$ and by fruit i.e. nitrogen $\left(83.59 \mathrm{~kg} \mathrm{ha}^{-1}\right)$, phosphorus $\left(20.18 \mathrm{~kg} \mathrm{ha}^{-1}\right)$ and potassium $\left(92.05 \mathrm{~kg} \mathrm{ha}^{-1}\right)$ was higher under drip irrigation at $75 \% \mathrm{PE}$ (I2) as compared to irrigation level I1 and I3. Total nutrient uptake i.e. nitrogen (137.79 $\left.\mathrm{kg} \mathrm{ha}^{-1}\right)$, phosphorus $\left(32.24 \mathrm{~kg} \mathrm{ha}^{-1}\right)$ and potassium $\left(148.38 \mathrm{~kg} \mathrm{ha}^{-1}\right)$ was also significant higher with $\mathrm{I}_{2}$ treatment. Drip irriga- tion at $75 \% \mathrm{PE}$ increase the nutrient uptake which may be due to approaching towards meeting the daily evaporation demand through drip irrigation, increased the availability of moisture resulting in higher nutrient uptake through its influence on biomass production and on the availability of nutrients. Preferential uptake of water from the sufficiently moist soil promoted the movement of nutrient ions towards roots and their uptake (Sanchez et al., 2001).

Effect of fertigation: The results in Table 3 revealed that nutrient uptake by plant i.e. nitrogen $(60.52 \mathrm{~kg} \mathrm{ha}$ $\left.{ }^{1}\right)$, phosphorus $\left(14.04 \mathrm{~kg} \mathrm{ha}^{-1}\right)$ and potassium $(64.58 \mathrm{~kg}$ $\mathrm{ha}^{-1}$ ) and by fruit i.e. nitrogen ( $\left.94.09 \mathrm{~kg} \mathrm{ha}^{-1}\right)$, phosphorus $\left(23.63 \mathrm{~kg} \mathrm{ha}^{-1}\right)$ and potassium $\left(104.98 \mathrm{~kg} \mathrm{ha}^{-1}\right)$ was higher under $75 \%$ RDF through fertigation +2 foliar spray of $1 \%$ urea phosphate (F3). Total nutrient uptake by crop i.e. nitrogen (154.62 $\left.\mathrm{kg} \mathrm{ha}^{-1}\right)$, phosphorus $\left(37.67 \mathrm{~kg} \mathrm{ha}^{-1}\right)$ and potassium $\left(169.56 \mathrm{~kg} \mathrm{ha}^{-1}\right)$ was also significant higher with $\mathrm{F}_{3}$ treatment. However, fertigation with $75 \% \mathrm{RDF}+2$ foliar spray of $1 \%$ urea phosphate and $100 \%$ RDF was found at par. The highest uptake of nitrogen, phosphorus and potassium at $75 \%$ RDF through fertigation +2 foliar spray of urea phosphate might be due to the fact that nitrogen increases the cation exchange capacity of plant roots and these make them more efficient in absorbing other nutrient ions like phosphorus and potassium. Increase in nitrogen uptake was due to increased availability of nitrogen in soil with higher rate of application (Kumar and Sahu, 2013 in cabbage and Kohire and Das, 2015 in chilli crop). The higher nitrogen, phosphorous and potassium, uptake was noticed at 75\% RDF through fertigation +2 foliar spray of urea phosphate treatment which might be due to fact that the cyclic regulation and continuous wetting of soil through drip irrigation maintained optimum moisture in the crop root zone which also reduces the force exerted by the plant to extract water and nutrients would be less. Further, application of nutrients number of splits in drip fertiga- 
Table 6. Combined effect of drip irrigation and fertigation levels on fruit yield, number of branches and plant height of tomato.

\begin{tabular}{|c|c|c|c|c|c|}
\hline Treatment & $\begin{array}{l}\text { Plant height } \\
\text { (cm) }\end{array}$ & $\begin{array}{c}\text { Number of } \\
\text { branches }\end{array}$ & Av. fruit weight (g) & $\begin{array}{l}\text { Av. fruit yield per } \\
\text { plant (kg) }\end{array}$ & $\begin{array}{c}\text { Fruit yield } \\
\left.(\mathrm{q} \mathrm{ha})^{-1}\right)\end{array}$ \\
\hline $\mathrm{I}_{1} \mathrm{~F}_{1}$ & 54.56 & 9.67 & 89.39 & 2.94 & 177.07 \\
\hline $\mathrm{I}_{1} \mathrm{~F}_{2}$ & 53.55 & 8.33 & 88.65 & 2.76 & 161.45 \\
\hline $\mathrm{I}_{1} \mathrm{~F}_{3}$ & 55.98 & 10.33 & 92.08 & 3.07 & 172.78 \\
\hline $\mathrm{I}_{1} \mathrm{~F}_{4}$ & 46.40 & 5.67 & 86.35 & 2.43 & 144.45 \\
\hline $\mathrm{I}_{1} \mathrm{~F}_{5}$ & 49.38 & 7.33 & 88.08 & 2.54 & 141.80 \\
\hline $\mathrm{I}_{2} \mathrm{~F}_{1}$ & 58.43 & 10.33 & 95.45 & 3.40 & 186.92 \\
\hline $\mathrm{I}_{2} \mathrm{~F}_{2}$ & 56.82 & 9.33 & 95.22 & 3.20 & 169.92 \\
\hline $\mathrm{I}_{2} \mathrm{~F}_{3}$ & 67.43 & 12.33 & 98.62 & 3.49 & 201.25 \\
\hline $\mathrm{I}_{2} \mathrm{~F} 4$ & 43.43 & 5.33 & 92.62 & 2.85 & 134.50 \\
\hline $\mathrm{I}_{2} \mathrm{~F}_{5}$ & 53.02 & 7.67 & 94.72 & 3.00 & 152.58 \\
\hline $\mathrm{I}_{3} \mathrm{~F}_{1}$ & 54.23 & 9.33 & 88.18 & 2.61 & 173.77 \\
\hline $\mathrm{I}_{3} \mathrm{~F}_{2}$ & 51.58 & 7.67 & 86.98 & 2.54 & 158.77 \\
\hline $\mathrm{I}_{3} \mathrm{~F}_{3}$ & 55.16 & 9.33 & 99.08 & 3.20 & 185.11 \\
\hline $\mathrm{I}_{3} \mathrm{~F}_{4}$ & 46.03 & 5.00 & 77.19 & 2.19 & 127.88 \\
\hline $\mathrm{I}_{3} \mathrm{~F}_{5}$ & 48.48 & 7.00 & 86.51 & 2.46 & 139.44 \\
\hline C.D. $5 \%$ & 3.21 & 1.02 & 6.16 & 0.12 & 12.552 \\
\hline
\end{tabular}

$\mathrm{I}_{1}=$ Drip irrigation at $100 \% \mathrm{PE} ; \mathrm{I}_{2}=$ Drip irrigation at $75 \% \mathrm{PE} ; \mathrm{I}_{3}=$ Drip irrigation at $50 \% \mathrm{PE} ; \mathrm{F}_{1}=100 \%$ RDF through fertigation; $\mathrm{F}_{2}=75 \% \mathrm{RDF}$ through fertigation, $\mathrm{F}_{3}=75 \% \mathrm{RDF}$ through fertigation +2 fpliar spray of $1 \%$ urea phosphate; $\mathrm{F}_{4}=50 \%$ $\mathrm{RDF}$ through fertigation; $\mathrm{F}_{5}=50 \% \mathrm{RDF}$ through fertigation +2 foliar spray of $1 \%$ urea phosphate.

tion resulted in minimum or no wastage of nutrients either through deep percolation or evaporation leading to higher uptake of nutrients as reported by Rajput and Patil (2006) in onion.

Combined effect of drip irrigation and fertigation: The combined effect of drip irrigation and fertigation proved superior to their individual effects (Table 4). Among different treatment combinations, $75 \% \mathrm{PE}+$ $75 \%$ RDF through fertigation +2 foliar spray of $1 \%$ urea phosphate through fertigation recorded maximum nutrient uptake by plant i.e. nitrogen $\left(65.65 \mathrm{~kg} \mathrm{ha}^{-1}\right)$, phosphorus (15.74 $\left.\mathrm{kg} \mathrm{ha}^{-1}\right)$ and potassium $(69.09 \mathrm{~kg}$ ha $\left.{ }^{-1}\right)$ and by fruit i.e. nitrogen $\left(101.17 \mathrm{~kg} \mathrm{ha}^{-1}\right)$, phosphorus $\left(25.85 \mathrm{~kg} \mathrm{ha}^{-1}\right)$ and potassium $\left(113.99 \mathrm{~kg} \mathrm{ha}^{-1}\right)$. Total nutrient uptake by tomato i.e. nitrogen $(166.83$ $\mathrm{kg} \mathrm{ha}^{-1}$ ), phosphorus (41.59 $\mathrm{kg} \mathrm{ha}^{-1}$ ) and potassium $\left(183.08 \mathrm{~kg} \mathrm{ha}^{-1}\right)$ was also found significant higher under treatment combination $\mathrm{I}_{2} \mathrm{~F}_{3}$. Similar results of increased uptake with fertigation have been reported earlier by Shedeed et al. (2009) in tomato with $100 \%$ RDF through fertigation and Kohire and Das (2015) in tomato crop.

\section{Growth characters, yield and yield attributes}

Effect of irrigation: The results of the experiment presented in Table 5 resulted that the growth characters viz., plant height $(55.83 \mathrm{~cm})$ and number of branches (9) and yield attributes viz., average fruit weight (95.32 g) and average fruit yield per plant $(3.19 \mathrm{~kg})$ and fruit yield $\left(169.03 \mathrm{q} \mathrm{ha}^{-1}\right)$ were significantly higher under (I2) $75 \% \mathrm{PE}$ as compared to irrigation level I1 and I3. The increase in yield might be due to better proportion of air and water in soil which maintained throughout the life period of crop in drip irrigation (Kadam and Karthikeyan, 2006 in tomato crop). The number of branches and plant height were significantly improved by the application of major nutrients through drip irri- gation at these boost the overall vegetative growth and biological efficiency of plant. The increase in tomato growth under drip irrigation system may be due to the availability of water when needed around the root zone at very low moisture tension. These results are in agreement with the findings of Yadav and Chouhan (2016) in brinjal at 1.2 $\mathrm{ET}_{\mathrm{c}}$ (drip). Gupta et al. (2015) also recorded higher average fruit weight (49.7 g) and fruit yield ( $893.4 \mathrm{q} \mathrm{ha}^{-1}$ ) in tomato crop with $80 \% \mathrm{ET}$ through drip fertigation.

Effect of fertigation: Results depicted in Table 5 revealed that the response of various fertigation levels in tomato revealed that among the various fertigation levels, $75 \%$ RDF through fertigation +2 spray of $1 \%$ urea phosphate produced maximum growth characters viz., plant height $(59.53 \mathrm{~cm})$ and number of branches (10.67) and yield attributes viz., average fruit weight $(96.59 \mathrm{~g})$ and average fruit yield per plant $(3.25 \mathrm{~kg})$ and fruit yield (186.38 q ha $\mathrm{q}^{-1}$ ) were significantly higher under F3 treatment. The application of $75 \%$ RDF through fertigation +2 spray of $1 \%$ urea phosphate increased fruit weight and fruit yield by 5.01 and 3.97 per cent over $100 \%$ RDF through fertigation. The highest fruit yield at higher level of nutrients may be due to favorable growth and higher nutrients uptake. Increased nitrogen would have resulted in higher growth while phosphorous would have higher root growth which might have helped in increased uptake of nutrients (Singh and Maurya, 1992). The another reason is that, increased level of fertigation leads to increased photosynthetic activities, protein synthesis and assimilate translocation due to suitable environmental condition that activates enzyme activities resulted in more growth attributes. These results are in agreement with the findings of Kavitha et al. (2007) in tomato crop and Yadav and Chouhan (2016) in brinjal 
with $75 \%$ RDF with six splits.

Combined effect of drip irrigation and fertigation: In case of interaction (Table 6), results revealed that the combined effect of drip irrigation and fertigation proved superior to their individual effects. The combined effect of drip irrigation and fertigation proved superior to their individual effects. Among different treatment combinations of $75 \% \mathrm{PE}+75 \% \mathrm{RDF}$ through fertigation +2 foliar spray of $1 \%$ urea phosphate through fertigation recoded maximum plant height $(67.43 \mathrm{~cm})$, number of branches (12.33), average fruit weight $(98.62 \mathrm{~g})$, average fruit yield per plant $(3.49 \mathrm{~kg})$ and fruit yield $\left(201.25 \mathrm{q} \mathrm{ha}^{-1}\right)$. Similar findings are also reported by Riazeian and Mahdavi (2005) in tomato crop and Vijayakumar et al. (2010) in brinjal crop with $75 \%$ ET and $75 \%$ RDF through drip fertigation.

\section{Conclusion}

From the present investigation it could be concluded that drip irrigation system found to be very promising in saving water and fertilizers, also controlling weed growth thereafter allowing plant to gain more water and nutrients which further tends to increase nutrient content and uptake in fruit and plant of tomato. Hence, growth, yield and nutrient uptake by tomato was found to be very significant with drip at $75 \% \mathrm{PE}$ and at $75 \%$ RDF through fertigation +2 foliar spray of $1 \%$ urea phosphate.

\section{REFERENCES}

Al-Mohammadi, F. and Al-Zu'bi, Y. (2011). Soil chemical properties and yield of tomato as influenced by different levels of irrigation water and fertilizer. Journal of Agriculture Science Technology, 13: 289-299

AOAC (2012). Official methods of analysis. $19^{\text {th }}$ Edition Association Official Analytical Chemists, W ASHINGTON, D.C.

Badr, M. A., Abou EI, A. A. and Yazied (2007). Effect of fertigation frequency from subsurface drip irrigation on tomato yield grown on sandy soil. Australian Journal of Basic and Applied Sciences, 1(3): 279-28

Doorenbos, J and Pruitt, W. O. (1977). Crop water requirements, FAO. Irrigation \& Drainage, Paper No. 24. U. N., Rome (Italy). Pp.144

Gupta, V. J., Chattoo, M. A. and Singh, Lal (2015). Drip irrigation and fertigation technology for improved yield, quality, water and fertilizer use efficiency in hybrid tomato. Journal of Agri. Research, 2(2): 94-99

Hari, H. R. (1997). Vegetable breeding principles and practices. Book Published by Kalyani Publication, pp. 1-4, NEW DELHI, INDIA.

Jackson, M. L. (1973). Soil chemical analysis. Pp. 498, Prentice Hall of India Pvt. Ltd., NEW DELHI, INDIA.

Kadam, J. R. and Karthikeyan. S. (2006). Effect of soluble NPK fertilizers on the nutrient balance, water use efficiency, fertilizer use efficiency of drip system in a tomato. International Journal of Plant Science, 1 : $92-94$

Kavitha, M., Natarajan, S., Sasikala, S. and Tamilselvi, C.
2007. Influence of shade and fertigation on growth, yield and economics of tomato (Lycopersiconesculentum Mill.). International Journal of Agriculture Science, 3 (1): 99-101

Kohire, V. O. P. and Das, J. C. (2015). Effect of drip irrigation and fertilizer management on capsicum (Capsicum annum L). Journal of Agriculture and Veterinary Science, 8(1):10-13

Kumar, P. and Sahu, R. L. (2013). Effect of irrigation and fertigation levels on cabbage. An Asian J. of Soil Sci., 8 (2): $270-274$

Nagaz, Kamel, Masmondi, Mohamed Moncef and Mochlia, Netij Ben (2012). Effects of deficit drip-irrigation scheduling regimes with saline water on pepper yield, water productivity and soil salinity under arid conditions of Tunisia. J. Agric. \& Environ. For Internat. Develop. - JAEID, 106(2): 85-103

Nijamodeen, M. S. and Dharmasena, P. B. (2002). Performance of chilli under drip irrigation with mulch. Annual of the Sri Lanka Department of Agriculture, 4: 89-94

Parkinson, J. A. and Allen, S. E. (1975). A wet oxidation procedure suitable for the determination of nitrogen and mineral nutrients in biological material. Coтmu. Soil. Sci. \& Plant Anal., 6:1-11

Rajput, T. S. and Patil, N. (2006). Water and nutrient movement in drip irrigated onion under fertigation and irrigation treatment. Agricultural Water Management, 79: 293 $-296$

Riazeian, S. and Mahdavi, M. (2005). Evaluation of tomato yields with different level of $\mathrm{N}$ and $\mathrm{K}$ fertigation. Transaction of the 19 International Congress on Irrigation and Drainage Beijing, China, Vol. 1A: Improving water and land management for increasing efficiency in irrigated agriculture. 16

Sanchez, R., Botia, P., Sironi, A., Crespo, P., Marin, A. and Nartinez, C. (2001). Vegetative growth and nutrient absorption in cauliflower. Investigation Agraria, ProductionY Proteccion Vegetable, 16(1): 119-130

Shedeed, S. I., Zaghlout, S. M. and Yassen, A. A. (2009). Effect of method and Rate of fertilizer application under drip Irrigation on yield and nutrient uptake by tomato. Ozean J. of Applied Sciences, 2(2)

Singh, S. S. and Maurya, A. N. (1992). Effect of nitrogen, phosphorus and potash on growth and yield of brinjal. Agriculture Science Digest, 12(1): 29-31

Vazquez, N., Pardo, A. and Suso, M. L. (2010). Effect of plastic mulch and quantity of $\mathrm{N}$ fertilizer on yield and $\mathrm{N}$ uptake of cauliflower with drip irrigation. Acta Horticulture, 852: 325-332

Vermerien, I. and Jobling, G. A. (1980). Localized irrigation design, installation, operation and evaluation. Irrigation and Drainage, FAO. 36: 10

Vijayakumar, G., Tamilmani, D. and Selvaraj, P. K. (2010). Irrigation and Fertigation Scheduling under Drip Irrigation in Brinjal (Solanum melongena L.) crop. Indian Journal of Bio-resource Management, 1: 72-76

Yadav, B. S. and Chouhan, R. P. S. (2016). Drip fertigation technology for enhancing technology and nutrient use efficiency in arid agro-ecosystem if irrigated NorthWestern Rajasthan. Annals of Arid Zone, 35 (3 \& 4): 139 $-145$ 